\title{
Effect of Guava Extract Administration on Megakaryocytes Amount in Mice Femur
}

\author{
Nur Atik ${ }^{1}$, Maqrizi D. S. Munawir ${ }^{2}$, Susan Tarawifa ${ }^{3}$, Hartati P. Darmadji ${ }^{4}$ \\ ${ }^{1}$ Department of Anatomy, Physiology, and Biology Cell, Faculty of Medicine, Universitas \\ Padjadjaran, Bandung, Indonesia, ${ }^{2}$ Medical Study Program, Universitas Padjadjaran, \\ Bandung, Indonesia, ${ }^{3}$ Master Program of Basic Medical Science, Universitas Padjadjaran, \\ Bandung, Indonesia, ${ }^{4}$ Department of Dermatology and Venerology, Faculty of Medicine, \\ Universitas Padjadjaran, Bandung, Indonesia/Dr. Hasan Sadikin General Hospital, Bandung, \\ Indonesia
}

\begin{abstract}
Dengue fever is a disease spread by mosquito's bite. Dengue fever is marked by the presence of thrombocytopenia. Traditional crops such as guava are commonly used to treat dengue fever. This research aims to know the effect of guava extract administration towards megakaryocytes amount in mice femur. The study was conducted at the Laboratory of Pharmacology and Therapy, Histology Laboratory of Faculty of Medicine at Universitas Padjadjaran, Eijkman, Bandung from September until November 2016 using laboratory experimental study design. 20 Swiss webster mice strains were divided randomly into 4 groups. Group I and II were administered quinine $2.8 \mathrm{mg} / 20 \mathrm{grBW} /$ day for 14 days to decrease amount of trombocytes. Group II and III were administered guava extract 0.785 $\mathrm{mg} / 20 \mathrm{grBW} /$ day for 5 days. Group IV was administered aquadest for 19 days. In the $27^{\text {th }}$ day, the mice left femurs were collected and made into paraffin section preparations with hematoxylin-eosin staining and then observed under microscope. Group IV had the most megakaryocytes followed by Group II, III, and I. Based on Kruskal-Wallis test, a significant difference was shown $(p<0.05)$. MannWhitney test showed that there were significant differences between Group I and Group II, III, and IV. Meanwhile there was no significant difference between normal mice and extract-given mice. Guava extract is proven statistically significant to increase the megakaryocytes amount in thrombocytopenic mice without increasing number of megakaryocytes in normal mice.
\end{abstract}

Keywords: Dengue fever, guava extract, megakaryocyte, quinine

\section{Efek Pemberian Ekstrak Jambu Biji terhadap Jumlah Megakariosit pada Femur Mencit}

\begin{abstract}
Abstrak
Demam berdarah merupakan penyakit yang dapat disebarkan melalui gigitan nyamuk. Demam berdarah ini ditandai dengan adanya trombositopenia. Tanaman tradisional berupa jambu biji banyak digunakan untuk mengobati demam berdarah. Penelitian ini bertujuan untuk mengetahui efek pemberian ekstrak jambu biji terhadap jumlah megakariosit pada femur mencit. Penelitian ini dilakukan di Laboratorium Farmakologi dan Terapi, Laboratorium Histologi Universitas Padjadjaran, Eijkman, Bandung dari bulan September hingga November 2016. Sebanyak 20 ekor mencit galur Swiss webster dibagi menjadi 4 kelompok. Kelompok I dan II diberikan quinine $2,8 \mathrm{mg} / 20$ grBB/hari per oral selama 14 hari agar mencit trombositopenia. Kelompok II dan III diberikan ekstrak jambu biji $0,785 \mathrm{mg} / 20 \mathrm{grBB} / \mathrm{hari}$ per oral selama 5 hari. Kelompok IV diberikan aquades selama 19 hari. Hari ke 27, femur mencit kiri diambil dan dijadikan sediaan parafin dengan pewarnaan hematoxylin-eosin, kemudian diamati di bawah mikroskop. Jumlah megakariosit terbanyak adalah pada Kelompok IV diikuti dengan II, III dan I. Berdasarkan uji Kruskal-Wallis, terdapat perbedaan bermakna $(\mathrm{p}<0,05)$ dilanjutkan uji Mann-Whitney yaitu terdapat perbedaan bermakna antara Kelompok I dengan II, III, dan IV, sedangkan perbandingan pada kelompok mencit normal dengan kelompok yang diberi ekstrak tidak terdapat perbedaan yang bermakna. Ekstrak jambu biji dapat meningkatkan jumlah megakariosit pada mencit yang mengalami trombositopenia dan tidak menyebabkan peningkatan jumlah megakariosit secara bermakna pada mencit normal.
\end{abstract}

Kata kunci: Demam berdarah, ekstrak jambu biji, megakariosit, quinine

Correspondence: Nur Atik, M.D., Ph.D., Department of Anatomy, Physiology, and Biology Cell, Faculty of Medicine, Universitas Padjadjaran, Sumedang, West Java 45363, Indonesia, email: n.atik@unpad.ac.id Received: $5^{\text {th }}$ January 2017, Accepted: $1^{\text {st }}$ May 2017, Published: $1^{\text {st }}$ June 2017 


\section{Introduction}

Dengue fever is a disease caused by dengue virus which could be transmitted by the Aedes (Ae) mosquito's bite especially $A e$. aegypti as the main vectors. ${ }^{1}$ About 50 million cases of dengue fever occur every year and based on the data according to World Health Organization (WHO), the incidence rate in 2007 reached 150,000 cases and mostly occured in Jakarta and West Java. ${ }^{2}$ Dengue fever could be characterized by one of the laboratory results in the form of a decrease in platelet count $<150,000$ cells $/ \mathrm{mm}^{3}$ called thrombocytopenia. ${ }^{3}$

Platelets are formed from the cytoplasm of megakaryocytes (MKs), their precursor cells, which reside in the bone marrow. Their generation is a 2-stage process entailing the differentiation of hematopoietic stem cells into mature megakaryocytes and release of platelets from MKs. There are many cytokines involved in platelets generation such as SCF, GM-CSF, TPO, IL-3, IL-6 and IL-1. ${ }^{4}$

Psidium guajava L. known as guava is a local fruit belonging to the family Myrtaceae. ${ }^{5}$ Guava is a well-known traditional plant used to treat dengue fever. ${ }^{6}$ The guava fruit contains vitamin $\mathrm{C}$, vitamin $\mathrm{A}$, iron, calcium, manganese, phosphorus, oxalate, and malic acid, morin-3-O $\alpha$-L-lyxopyranoside, morin$3-\mathrm{O}-\alpha$-L-arabopyranoside, combinations of saponin and oleanolic acid, flavonoids, quercetin, and guaijavarin. ${ }^{5}$

Based on Wiyasihati and Soegijanto's research, the extract of guava leaf was proven to increase interleukin (IL)-3 and granulocyte macrophage colony-stimulating factor (GMCSF) thereby improving megakaryopoiesis process. Therefore, it could increase platelets in the dengue fever patients. ${ }^{1,7}$ According to a study by Andrianto, the guava juice proved to have significant effect on platelet counts. ${ }^{8}$

There had been no research on the effects of guava fruits extract, consequently, the researchers wanted to know whether there is any effect of guava extract to the production of megakaryocytes as precursors of platelets in the femur of normal mice and mice induced thrombocytopenia using quinine. This study aims to determine the effects of the extract of guava on megakaryocyte amount in mice femur.

\section{Methods}

The study was conducted at the Laboratory of Pharmacology and Therapy, Histology Laboratory of Faculty of Medicine at Universitas Padjadjaran, Eijkman, Bandung from September until November 2016 using laboratory experimental study design.

Guava extraction

Fresh guava fruits were collected from a farmland located in Dukuh Waluh village, Purwokerto, Central Java, Indonesia. Guava extract was obtained and extracted using ethanol at Research Laboratory of Department of Chemistry, Universitas Padjadjaran, Singaperbangsa, Bandung. The extraction was made by cutting the guava fruits into small pieces, thereafter they were heated and dried in the oven. The dried guava pieces were then blended with $70 \%$ ethanol and underwent maceration process. ${ }^{9}$

\section{Animal treatment}

The research objects were male mice (Mus musculus), Swiss webster strain as much as 20 mice, aged 8-12 weeks, weighing 20-30 grams that had been previously been adapted for 7 days before being treated. This research was conducted by observing 3R (Reduction, Replacement, Refinement) aspects. The number of the required research objects was determined using resource equation method. This study had been approved and licensed by the Health Research Ethics Committee, Universitas Padjadjaran (Number of ethical 
clearance: 011606060$).{ }^{10,11}$

The inclusion criteria for this study was the mice must be healthy marked by the absence of wound, its hair was clean, and moving actively. Some of the mice were excluded because they were sick or their body weight reduced more than $10 \%$ after adaptation.

The mice were randomly divided into four groups, with five mice in each group. Group I and Group II was given quinine as much as $2.8 \mathrm{mg} / 20 \mathrm{grBW} /$ day per oral for 14 days from day 8 through day 21 . Then the guava extract was given as much as $0.785 \mathrm{mg} / 20$ grBW/day per oral for 5 days for Group II and Group III on day 22 until day 26. Group III was given distilled water on day 8 until day 21, and Group IV as a normal group was given distilled water only on day 8 until day 26 (Figure 1).

Quinine dose given to mice were obtained from a previous study by Andrianto et al., which was $100 \mathrm{mg} / \mathrm{kg} /$ day for 14 days against mice. ${ }^{8}$ So this study used dose of quinine that has been converted into mice with a conversion value of 0.14 which was 2.8 $\mathrm{mg} / 20 \mathrm{grBW} /$ day for 14 days.

The guava extract dose used in this study was adopted from a previous study on the treatment of dengue fever by Harjono who explained that supplementation of guava leaf extract as much as two capsules 500 mg. Each capsule contains $2.655 \mathrm{mg}$ given quercetin. ${ }^{7}$ The dose of quercetin converted into mice with a 0.0026 conversion values was $0.0193 \mathrm{mg} / 20 \mathrm{grBB}$ mice. The guava extract was known to contain quercetin according to previous research by Soegijanto et al., namely $2.46 \%$ or $2.46 \mathrm{mg} / 100 \mathrm{mg}$ of extract. ${ }^{7}$ Finally, we got the dose to extract of guava: $0.785 \mathrm{mg} / 20 \mathrm{grBB} /$ day to mice.

\section{Histological analysis}

On day 27, the mice were anaesthetized using a combination of ketamine and xylazine intraperitoneally with doses $0.1 \mathrm{~mL} / 20$ grBB. After anesthesia worked, part of the left femur of the mice were taken and inserted into formalin as a transport medium. Then mice femur made as a paraffin section preparation that stained with hematoxylin-eosin.

The preparation was observed under microscope with 10x and 40x magnification quantitatively by counting megakaryocytes femur of 3 samples each sample preparation and each seen three visual field. The result of the calculation in units of the amount of megakaryocytes in this study was the number of megakaryocytes/low power field (LPF).

Statistical analysis

Data were calculated and analyzed using One-Way Anova. This test was a parametric

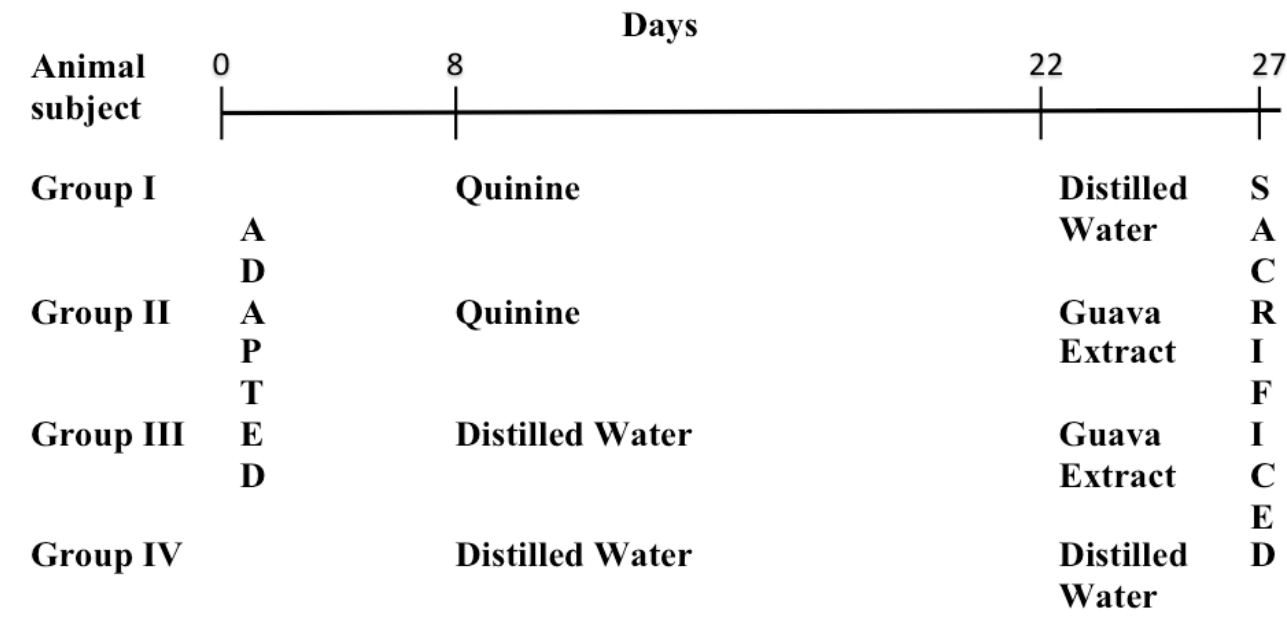

Figure 1 Schematic Draw of Timeline for Animal Treatment 
test that had two terms which are normally distributed data and had a homogeneous variant. If these conditions were not matched, then alternative non-parametric tests were used such as Kruskal-Wallis test to compare the amount of megakaryocytes among the groups, with significance $p$-value of $<0.05$. If the value of $p<0.05$ then post-hoc test was done using the Mann-Whitney test.

\section{Results}

After the mice were sacrificed, mice femurs were taken and made as paraffin section preparations. Subsequently, they were observed under microscope and megakaryocytes counted using preparations overview of each of the visual field (Figure 2 ). Based on statistical data analysis, the highest average number of megakaryocytes was in Group IV, followed by Group II, III, and I (Figure 3).

This test used the Shapiro-Wilk normality then conducted in order to indicated the $\mathrm{p}$ of Group I (quinine) $=0.678, \mathrm{p}$ of Group II (quinine + guava extract) $=0.579, \mathrm{p}$ of
Group III (distilled water + guava extract $)=$ 0.097 , and $\mathrm{p}$ of Group IV (distilled water) $=$ 0.003 , therefore the data was not normally distributed with the value of $p$ of $<0.05$. The homogeneity test results using Levene test showed the value of $p=0.325$, it means the data had a homogeneous variance value $p>$ 0.05 . The homogeneity test was followed by data analysis using the Kruskal-Wallis test which resulted significant difference between Group I and Group II, III and IV (p $<0.05$ ). Hence, according to these results, it could be concluded that the administration of guava extract could increase the number of megakaryocytes. Meanwhile, between the group of normal mice, Group II and Group III did not show any significant differences ( $\mathrm{p}$ $>0.05$ ) (Table 1).

\section{Discussion}

Post-quinine administration of $2.8 \mathrm{mg} /$ $20 \mathrm{grBB} /$ day dose orally for 14 days resulted the average of 16.80 cell/LPF of megakaryocytes. Comparison between the results in each group showed that the average
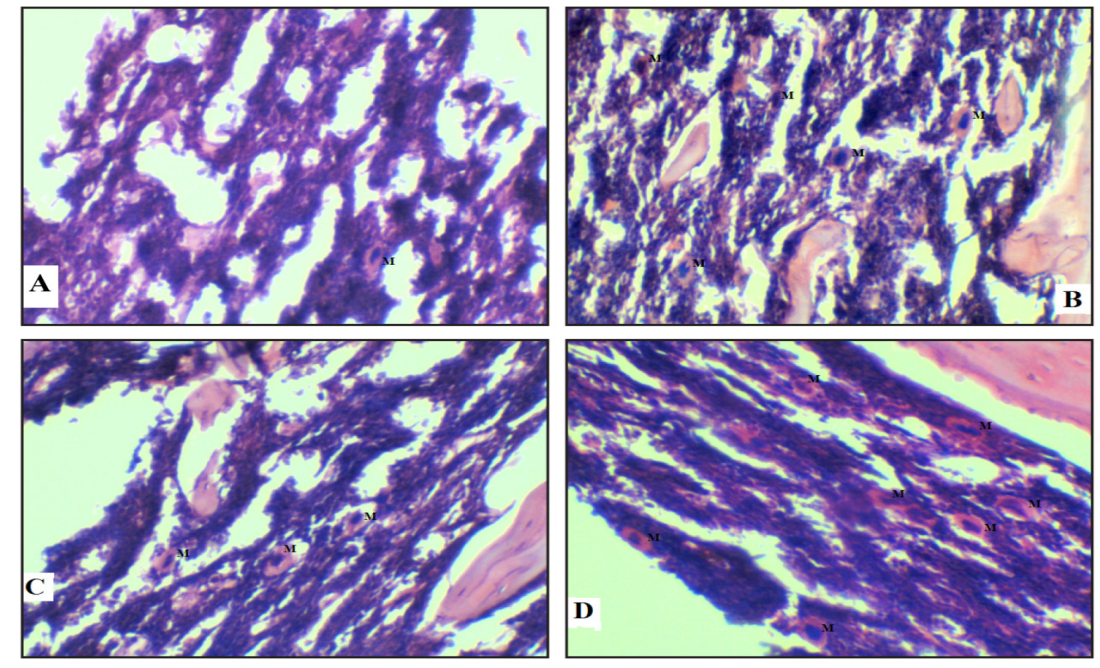

Figure 2 Bone Marrow of Mice Femur

After guava extract treatment, mice were sacrificed and femur was collected for HE staining. Quantitative observation of megakaryocytes in the bone marrow showed that number of megakaryocytes in Group I (A) is significantly different compared to Group II (B). Furthermore, there is no statistically difference between Group II and Group III (C) or Group IV (D). Microscopic image of 10x magnification and $\mathrm{M}$ is megakaryocyte. 


\section{Megakaryocyte Average Amount (cell/LPF)}

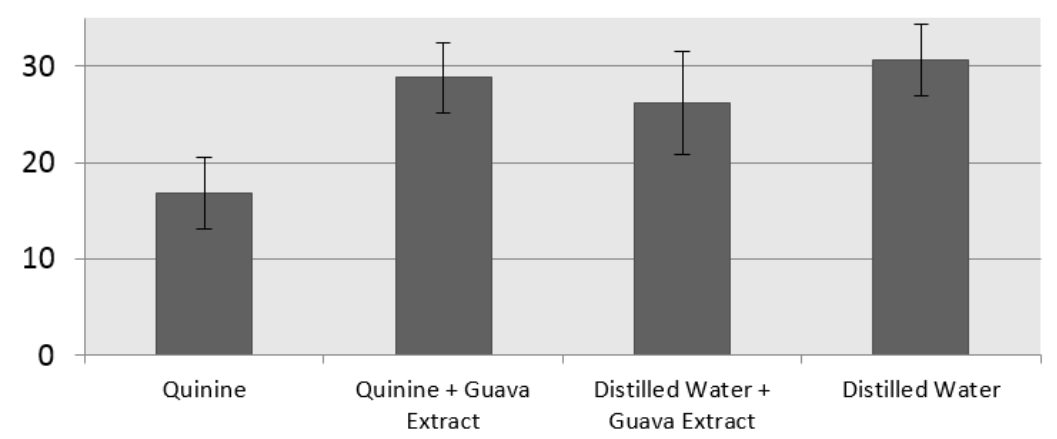

Figure 3 Differences of the Average Number of Megakaryocyte After Treatment

number of megakaryocytes in the Group I was the smallest. The administration of high dose quinine could cause thrombocytopenia and a decrease in megakaryocytes number. Mechanism of action of quinine in order to reduce the number of megakaryocytes is by binding with megakaryocytes surface antigens, such as GPIB, IX and GPIIb, and IIIa antigens which were similar to thrombocyte. ${ }^{12}$

The combination of $2.8 \mathrm{mg} / 20 \mathrm{grBW} /$ day quinine orally for 14 days and 0.785 $\mathrm{mg} / 20 \mathrm{grBW} /$ day guava extract for 5 days generated an increase in the average number of megakaryocytes compared to the group who were given quinine only. ${ }^{13,14}$ Guava contains vitamin $\mathrm{C}$, vitamin $\mathrm{A}$, iron, calcium, manganese, phosphorus, oxalate and malic acid, morin-3-O $\alpha$-L-lyxopyranoside, morin3-O- $\alpha$-L-arabopyranoside, combinations of saponin and oleanolic acid, flavonoids, quercetin, and guaijavarin. ${ }^{5}$

Based on previous research by Wiyasihati et al. (2013), Soegijanto et al. (2010), and Andrianto et al. (2015), it is stated that the content of quercetin in guava could increase the number of megakaryocytes and thrombocytes. ${ }^{1,7,8,15}$ Quercetin was known to stimulate hematopoietic stem cells production as a precursor of the formation of mice blood. ${ }^{15}$ Administration of quercetin in mice could make the expression of mRNA of stem cells factor (SCF), GM-CSF, and erythropoietin (Epo) in bone marrow stromal cells increase. Moreover, quercetin cytokines could stimulate hematopoiesis in bone marrow stroma in order to promote the differentiation of hematopoietic stem cells (HSC). HSC subsequently transformed into myeloid stem cells with the help of some factors such as IL-1, IL-6, and IL-3. Thereafter, it would be converted into colony forming units-granulocyte, erythroid, monocyte macrophage, megakaryocyte (CFU-GEMM) with the help of a factor GM-CSF and IL3. Research conducted by Soegijanto et al. mentioned that quercetin might increase GM-CSF and IL-3 to accelerate the process of megakaryocytes formation. CFU-GEMM would be converted into precursors of megakaryocytes which was colony forming

Table 1 Mann-Whitney Test Result from the Average Number of Megakaryocytes

\begin{tabular}{ccccc}
\hline Group & I & II & III & IV \\
\hline I & - & $0.009 *$ & $0.012^{*}$ & $0.008^{*}$ \\
II & $0.009^{*}$ & - & 0.462 & 0.287 \\
III & $0.012^{*}$ & 0.462 & - & 0.118 \\
IV & $0.008^{*}$ & 0.287 & 0.118 & - \\
\hline
\end{tabular}

*p-value $<0.05$ considered significantly different 
unit-megakaryocyte (CFU-meg), and then converted into megakaryoblast with the help of GM-CSF and IL-3. Megakaryoblast was then converted into megakaryocytes with the help of thrombopoietin. Therefore, guava extract administration was assumed to increase the number of platelets in patients with dengue fever which was the result of increasing the number of megakaryocytes. ${ }^{7}$

Hereafter, the normal group and the group which were given guava extract showed no significant difference. These results indicated that administration of guava extract could not increase megakaryocytes or platelets in mice with normal circumstances. This proved that the quercetin component in guava did not affect the homeostasis in the form of megakaryocytes formation. Megakaryocyte formation was influenced by the presence of thrombopoietin in blood circulation. This thrombopoietin receptor binds to c-MPL on megakaryocytes to stimulate the formation of megakaryocytes. In the state of thrombocytopenia, thrombopoietin levels in circulation increased, so it bound to c-MPL to help improve megakaryocytes. Meanwhile, in normal circumstances, the platelet count was within normal limits. These platelets would then bind to circulatory thrombopoietin and did not increase megakaryocyte production. ${ }^{16}$ So it could be assumed that the administration of guava extract could not increase the number of megakaryocytes or platelets in normal individuals as quercetin only affects factors which stimulate the formation of megakaryocytes but not affect the levels of thrombopoietin.

Limitation of this study was unknown dose of quercetin content in guava extract given to the treated group. The unknown molecular mechanism of quercetin in guava associated with formation of megakaryocytes and this study did not use a variable dose, so it cannot determine the most effective dose in order to increase the number of megakaryocytes.
Suggestion for the future research is to conduct research to provide a dose of guava extract varied with quercetin level test beforehand. Furthermore, to know the mechanism of quercetin in guava, further research is needed to determine the molecular pathway effects of quercetin.

\section{Conclusions}

Administration of guava extract at doses of $0.785 \mathrm{mg} / 20 \mathrm{grBB} /$ day was statistically proven to increase the number of megakaryocytes in mice that experienced thrombocytopenia. Meanwhile, in normal mice, the extract of guava could not significantly increase the number of megakaryocytes.

\section{Acknowledgements}

We would like to thank Mr. Mumuh and Mr. Irfan as laboratory personnels who have helped in the course of this study.

\section{Funding}

This research was not funded by any source of grant.

\section{Conflict of Interest}

Entire authors declare there were no potential conflict of interest with the research, authorship, and/or publication of this article.

\section{References}

1. Wiyasihati SI, Wigati KW, Wardani T. Comparing the effect of red yeast rice, date palm, and guava leaf extract on thrombocyte and megakaryocyte count in thrombocytopenic white rats. Folia Medica Indones. 2013; 49(2):82-7.

2. World Health Organization. Dengue: Guidelines for diagnosis, treatment, 
prevention, and control. Spec Program Res Train Trop Dis; 2009.

3. World Health Organization Regional Office for South-East Asia. Comprehensive guidelines for prevention and control of dengue and dengue haemorrhagic fever. World Health Organization; 2011.

4. Eto K, Kunishima S. Linkage between the mechanism of thrombocytopenia and thrombopoiesis. Blood. 2016;127(10):1234 -41. doi: 10.1182/blood-2015-07-607 903

5. Barbalho SM, Machado FMVF, deAlvares GR, Brunnati ACS, Otoboni AM, et al. Psidium guajava (guava): A plant of multipurpose medicinal applications. Med Aromat Plants. 2012;1(4):1-6. doi: 10.4 172/2167-0412.1000104

6. Kadir SLA, Yaakob H, Zulkifli RM. Potential anti-dengue medicinal plants: A review. J Nat Med. 2013;67:677-89. doi: 10.1007/s11418-013-0767-y

7. Soegijanto SAMS, Tumbelaka AR, Anggraini, Rufiati R, Sary DD. Uji klinik multisenter sirup ekstrak daun jambu biji pada penderita demam berdarah dengue. J Med. 2010;23(1):5-10.

8. Andrianto D, Satyaningtijas AS, Rosary F. Combination of angkak (red yeast rice), red guava (Psidium guajava Linn) leaf extract and red guava fruit juice increase thrombocyte in quinine-exposed rats. IOSR J Pharm. 2015;5(4):1-6.

9. Azwanida NN. A review on the extraction methods use in medicinal plants, principle, strength and limitation. Med Aromat Plants. 2015;4(3):3-8. doi: 10.4172/216 7-0412.1000196
10. Charan J, Kantharia N. How to calculate sample size in animal studies? J Pharmacol Pharmacother. 2013;4(4):303-6. doi: 10. 4103/0976-500X.119726

11. Ridwan E. Etika pemanfaatan hewan percobaan dalam penelitian kesehatan. J Indones Med Assos. 2013;63(3):112-6.

12. Perdomo J, Yan F, Ahmadi Z, Jiang XM, Stocker R, Chong BH. Quinine-induced thrombocytopenia: Drug-dependent GPIb/ IX antibodies inhibit megakaryocyte and proplatelet production in vitro. Blood. 2011;117(22):5975-86. doi: 10.1182/blo od-2010-10-314310

13. Joseph B, Mini Priya R. Review on nutritional, medicinal and pharmacological properties of guava (Psidium guajava Linn.). Int J Pharma Bio Sci. 2011;2(1): 53-69.

14. Wang F, Chen Y, Zhang Y, Deng G, Zou Z, Li A. Chemical components and bioactivities of Psidium guajava. Int $\mathrm{J}$ Food Nutr Saf. 2014;5(2):98-114.

15. Shin SK, Kim TW, Youm SY, Kim Y, Ahn B. Quercetin 3-O- $\beta$-(2"-galloyl)rhamnopyranoside promotes the differentiation of hematopoietic stem cells or early progenitor cells into erythroid lineage in mice. J Med Plant Res. 2011; 5(21):5276 -83.

16. Machlus KR, Thon JN, Italiano JE. Interpreting the developmental dance of the megakaryocyte: A review of the cellular and molecular processes mediating platelet formation. Br J Haematol. 2014;165(2): 227-36. doi: 10.1111/bjh.12758 